\title{
Excessive Soft Tissue Reaction after Stereotactic Body Radiation Therapy in a Woman with Four Different Cancer Diagnoses
}

\author{
Martin Turzer Odd Terje Brustugun Åslaug Helland \\ Oslo University Hospital Radiumhospitalet, Oslo, Norway
}

\section{Key Words}

Stereotactic body radiotherapy - Soft tissue reaction - Multiple malignancies

\begin{abstract}
Patients experiencing several cancers can be a challenge, as optimal treatment options for the different cancers might interfere with each other. In this case report, we present a woman diagnosed with 4 different types of cancer. She was treated with surgery, chemotherapy and radiotherapy. Her performance status was generally good, and she tolerated the treatment very well, except some troublesome side effects in the thoracic soft tissue after stereotactic body radiotherapy.
\end{abstract}

\section{Case Report}

A 65 -year-old woman with a smoking history of about 45 pack-years was referred to our clinic. In 1986, she had been treated for a cervical cancer stadium T2b with intracavitary brachytherapy and external radiation of the pelvis up to $50 \mathrm{~Gy}$. Apart from chronic urge incontinence, she had developed no acute or late toxicity after radiotherapy. Controls showed no sign of relapse. In November 2007, she was diagnosed with a stage I, node-negative breast cancer. In preparation of adjuvant radiotherapy after breast-conserving surgery, a chest X-ray showed two pulmonary nodules, one in the right upper lobe and one in the left upper lobe. By that time, she was in good performance status, had no pulmonary symptoms and no weight loss. Physical examination revealed no pathological findings.

Thoracic CT scan showed a $29 \times 30 \times 25 \mathrm{~mm}$ spiculated lesion in the right upper lobe. In the left upper lobe, a conflating lesion of $15 \times 19 \times 8 \mathrm{~mm}$ was detected. There was no mediastinal lymphadenopathy. None of the lesions were in range for bronchoscopic biopsy, but CT-guided biopsy of the nodule in the right lung was performed. A poorly differentiated squamous cell carcinoma was diagnosed and the limited biopsy material showed positive staining for CK 7, 5 and 6, BerEP4 and TTF1. The pathologists could not definitely conclude if it was a primary lung carcinoma or a relapse from her cervical cancer. The postoperative radiotherapy to the breast was cancelled. 
After interdisciplinary discussion, it was decided to start combination chemotherapy with topotecan and cisplatin, as the tumour was considered a cervical cancer metastasis. After 6 cycles with moderate toxicity, CT revealed that the nodule in the left lung was no longer apparent. Unfortunately, there was a significant growth of the lesion in the right lung, and a 18FDG-PET/CT showed intense metabolic activity with high uptake of FDG in the tumour with a standardised uptake value (SUV) of 34 (fig. 1). Surprisingly, pathological uptake in a nodule in the proximal rectum with an SUV of 12 was also found. MRI of the pelvis was performed and a colonoscopy with biopsy verified a highly differentiated adenocarcinoma in the sigmoideum, staged as Duke A. The patient underwent an abdominal rectosigmoid resection and colorectal anastomosis.

Due to the inconclusive histopathological evaluation of the tumour in the right upper lobe, the limited effect of chemotherapy, and the radiological consistence with primary lung cancer, it was concluded that this tumour most likely was a primary lung carcinoma, and a radical approach was recommended. Due to chronic obstructive pulmonary disease, the patient had severe reduction of lung function, excluding her from thoracic surgery and conventional radiotherapy. The only remaining curative alternative was a high-dose stereotactic body radiotherapy (SBRT) for her primary T2a lung cancer. In December 2008, the patient underwent a 4-dimensional CT-gated SBRT against the lesion in the right upper lobe (fig. 2). SBRT was performed to a total dose of $45 \mathrm{~Gy}$, delivered in 3 fractions given every other day. Image guidance with on-board CT scan was performed to re-localize the target lesion before every treatment delivery. The patient accomplished treatment without acute toxicity.

Six weeks after SBRT, the patient presented with intense thoracic pain requiring moderate morphine doses, chest wall oedema and fever. CT scan showed significant tumour reduction from $29 \times 30 \times$ $25 \mathrm{~mm}$ to $20 \times 22 \times 18 \mathrm{~mm}$, consolidating lung parenchyma and atelectasis due to stricture of a segment bronchus and a pronounced thoracic oedema. These early complications after high-dose stereotactic radiotherapy are well documented, but are rare in this intensity [1]. The solid swelling over the right chest wall corresponded to the radiation field. In order to eliminate the possibility of a relapse, biopsies were taken, showing inflammatory tissue without evidence of atypical cells. After treatment with corticosteroids, nonsteroidal anti-inflammatory drugs and morphine for 3 months, the clinical and radiological alterations reversed and medication could be reduced. PET-CT showed a markedly inflammatory response in the chest wall without uptake suspicious of malignancy. The patient was followed up with alternating CT scans and PET-CT every 3 months, and a total regression of the clinical symptoms was registered after 1 year (fig. 3 ). One and a half year after SBRT, she was without clinical or metabolic indicators of tumour activity. Nevertheless, a minor chest wall oedema and mild lung fibrosis around the high-dose area without clinical impact could be verified.

\section{Discussion}

Multiple synchronous or metachronous malignancies are not rare. Estimates between 0.73 and $11.7 \%$ are published [2]. Treating a patient with multiple malignancies can be challenging. Previous treatment with surgery, chemotherapy and radiation therapy can lead to severe comorbidity that may have an impact on further possibilities of effective cancer treatment. The technological development in radiotherapy has undergone an era of unprecedented transformation, allowing the precise and non-invasive administration of high radiation doses in an aggressive, decisive manner to eradicate a discrete focus of cancer, and has opened a new treatment option for patients who formerly had no curative alternative. High-dose SBRT for early-stage lung cancer is a well-established, welldocumented and safe approach [3-5].

Acute pneumonitis or fibrosis is regularly seen radiographically after SBRT, but such findings are usually without clinical relevance even though many patients undergoing SBRT have reduced lung function. In our case, acute pneumonitis and stricture of a segment bronchus with consecutive atelectasis developed already 6 weeks after SBRT and diminished after 1 year. These pulmonary side effects had no clinical impact on the patient's everyday life. Studies measuring pulmonary function before and after treatment with SBRT have not shown permanent declines in function [4]. Skin erythema, fractures of the ribs, vertebral body, chest wall inflammation, and acute and chronic chest pain are 
side effects that may appear in high-dose areas. For chronic chest pain and rib fracture after SBRT, a dose-response correlation and a dose-volume relationship are well documented [6,7]. In our patient, the dose per fraction to $2 \mathrm{~cm}^{3}$ of the rib was $13.9 \mathrm{~Gy}$ and the volume of the chest wall receiving $>30 \mathrm{~Gy}$ was $67 \mathrm{~cm}^{3}$. Both values exceeded the recommended doses by factor 1.5 and 2.2. These findings may explain our patient's chest wall toxicity. In SBRT, the type of side effects depends on the tumour location. The minimum distance from our patient's lesion to the chest wall was only $25 \mathrm{~mm}$, which unavoidably gives a high dose contribution to the chest wall. Chronic chest pain is also a common problem after thoracic surgery in up to $10 \%$ of patients, and the response to treatment is poor [8]. Our patient's soft tissue reaction could be influenced by the radiosensitizing effect of cisplatin [9-11]. Even if the time interval between chemotherapy and SBRT in our patient was 5 months, one can speculate about a contributing effect of cisplatin on the excessive soft tissue reaction after SBRT. This theory is supported by the fact that our patient had tolerated high doses given to the pelvis in 1986. A third option is that she is genetically susceptible to cancer and to radiotherapeutic side effects due to her genetic characteristics involved in DNA repair. Our knowledge about the genetics underlying differences in normal tissue radiosensitivity is still sparse, and there are no obvious candidate genes identified [12].

Our case illustrates some of the challenges and possibilities of modern cancer treatment. After diagnosed with cancer for the first time, our patient has survived 4 lifethreatening cancer diagnoses. She is in excellent condition and according to her, she has more courage to face life than ever. 


\begin{tabular}{c|l|l|l}
$\begin{array}{c}\text { Case Reports in } \\
\text { Oncolady }\end{array}$ & $\begin{array}{l}\text { Case Rep Oncol 2010;3:195-201 } \\
\text { D0I: 10.1159/000317104 }\end{array}$ & Published online: June 26, 2010 & $\begin{array}{l}\text { O 2010 S. Karger AG, Basel } \\
\text { ISSN 1662-6575 } \\
\text { www.karger.com/cro }\end{array}$ \\
\hline
\end{tabular}

Fig. 1. PET-CT of the tumour in the right lung.

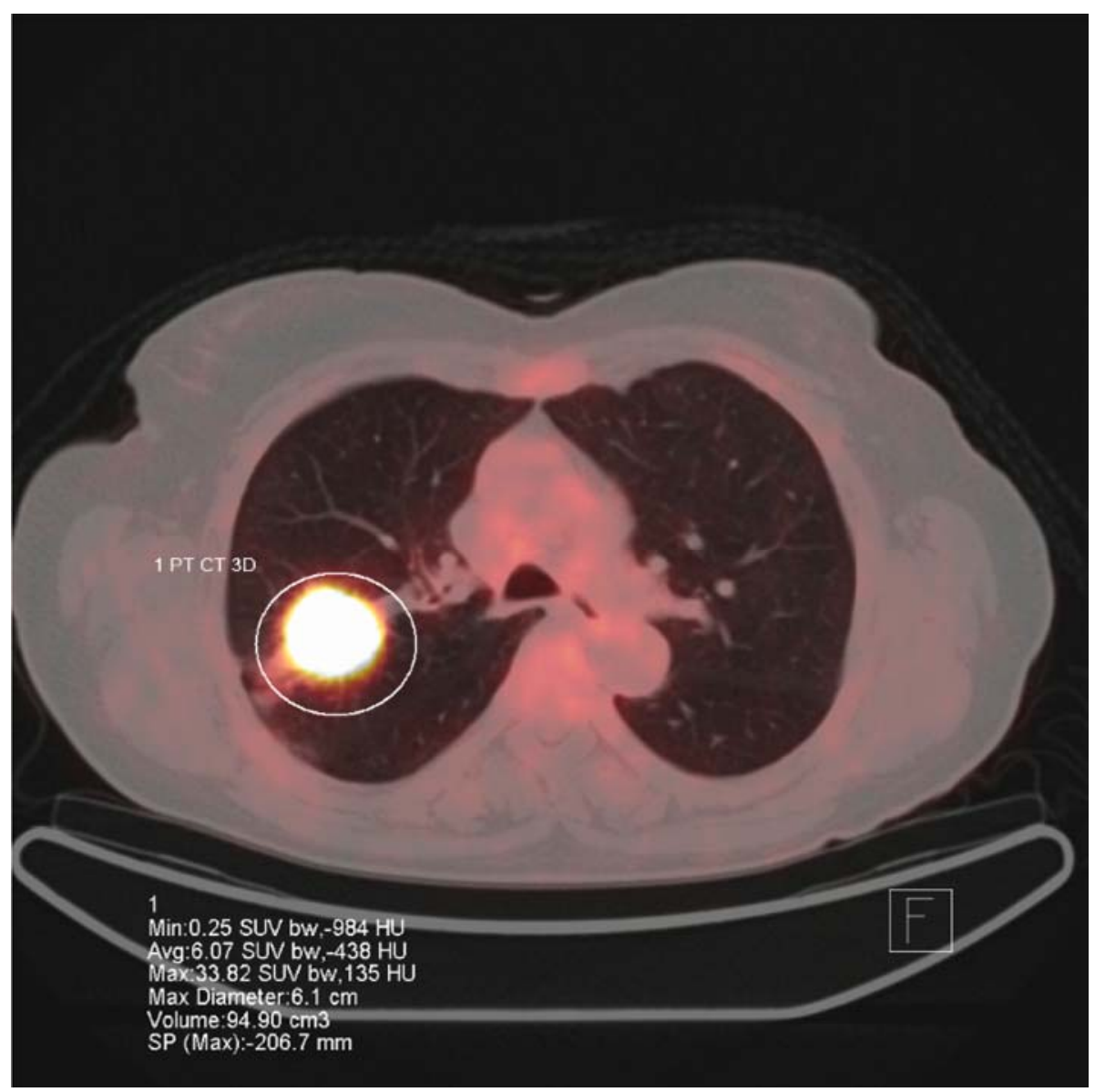




\begin{tabular}{c|l|l|l}
$\begin{array}{c}\text { Case Reports in } \\
\text { Oncolady }\end{array}$ & $\begin{array}{l}\text { Case Rep Oncol 2010;3:195-201 } \\
\text { D0I: 10.1159/000317104 }\end{array}$ & Published online: June 26, 2010 & $\begin{array}{l}\text { O 2010 S. Karger AG, Basel } \\
\text { ISSN 1662-6575 } \\
\text { www.karger.com/cro }\end{array}$ \\
\hline
\end{tabular}

Fig. 2. Radiation field in the planning CT prior to SBRT.

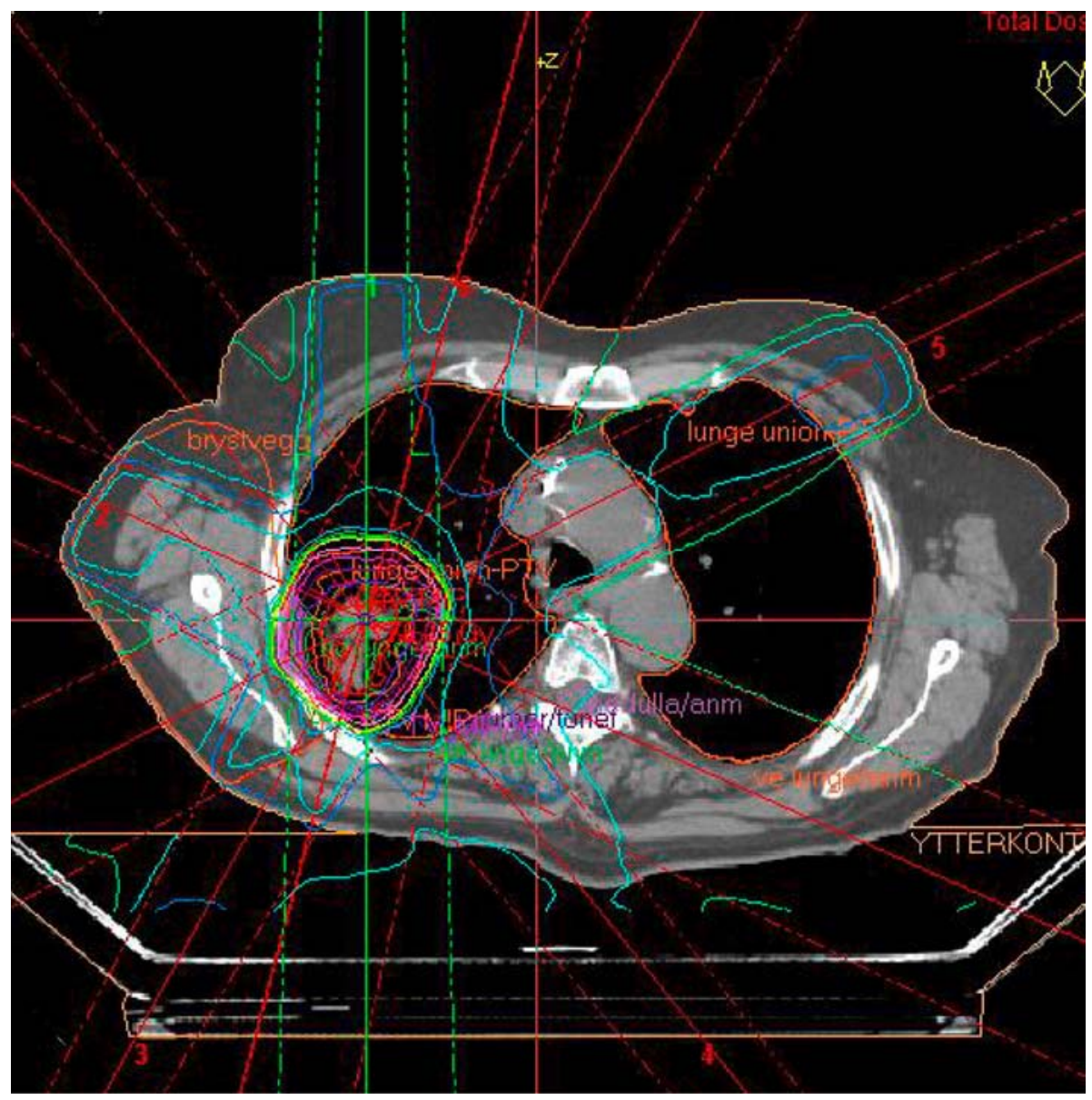




\begin{tabular}{c|l|l|l}
$\begin{array}{c}\text { Case Reports in } \\
\text { Oncolady }\end{array}$ & $\begin{array}{l}\text { Case Rep Oncol 2010;3:195-201 } \\
\text { D0I: 10.1159/000317104 }\end{array}$ & Published online: June 26, 2010 & $\begin{array}{l}\text { O 2010 S. Karger AG, Basel } \\
\text { ISSN 1662-6575 } \\
\text { www.karger.com/cro }\end{array}$ \\
\hline
\end{tabular}

Fig. 3. Thoracic PET-CT showing inflammation after SBRT.

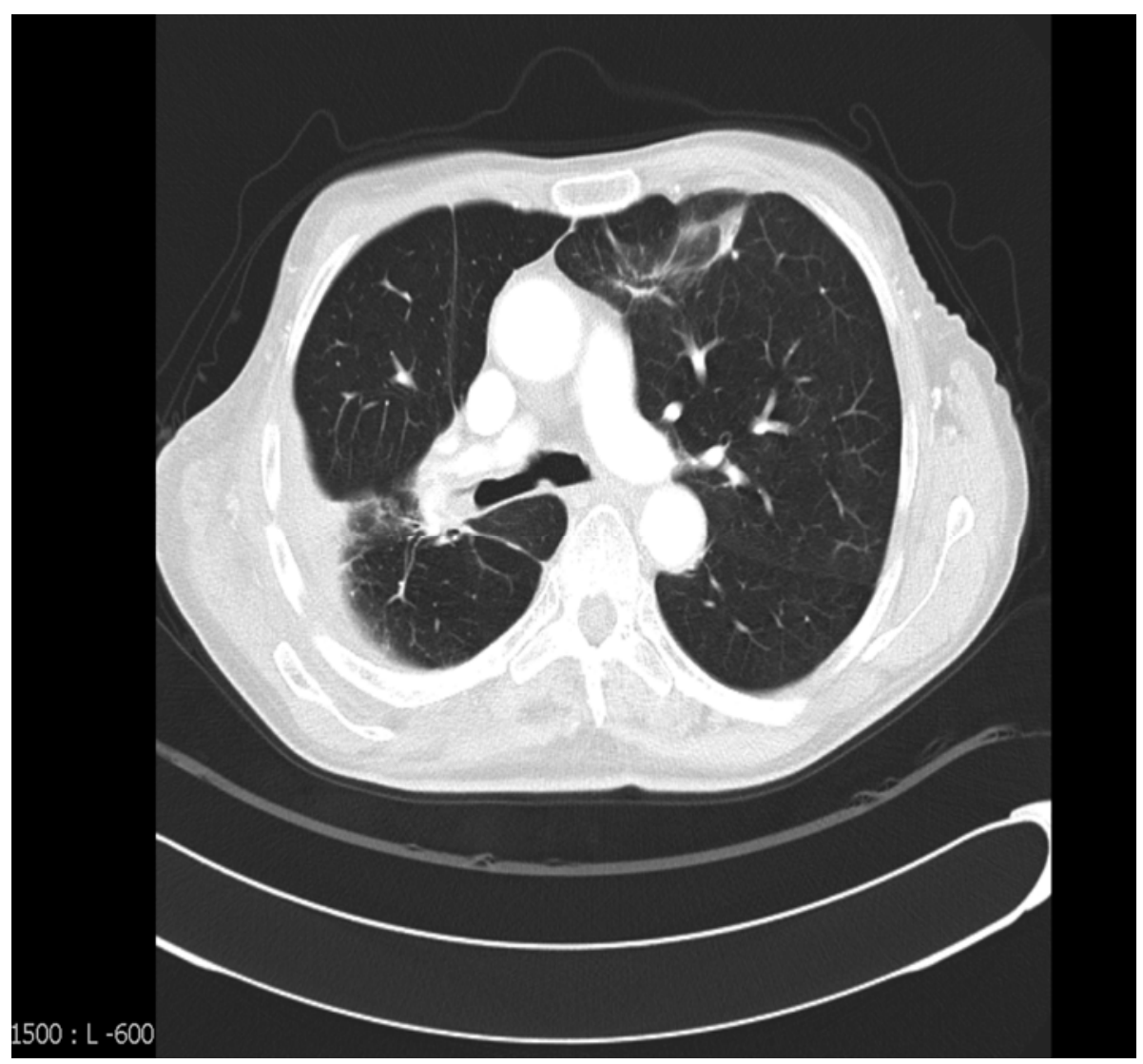




\begin{tabular}{|c|c|c|c|}
\hline $\begin{array}{c}\text { Cose Reports in } \\
\text { Onacily }\end{array}$ & $\begin{array}{l}\text { Case Rep Oncol 2010;3:195-201 } \\
\text { Dol: 10.1159/000317104 }\end{array}$ & Published online: June 26, 2010 & \begin{tabular}{|l} 
@ 2010 S. Karger AG, Basel \\
ISSN 1662-6575 \\
www.karger.com/cro
\end{tabular} \\
\hline
\end{tabular}

\section{References}

-1 Hof H, Herfarth KK, Muenter M, Hoess A, van Kaick G, Wannenmacher M, Debus J: Stereotactic single-dose radiotherapy of stage I non-small-cell lung cancer. Int J Radiat Oncol Biol Phys 2003;56:335-341.

$\checkmark 2$ Demandante CG, Troyer DA, Miles TP: Multiple primary malignant neoplasms: case report and a comprehensive review of the literature. Am J Clin Oncol 2003;26:79-83.

>3 Onishi H, Araki T, Shirato K, Nagata Y, Hiraoka M, Gomi K, Niibe Y, Karasawa K, Hayakawa K, Takai Y, Kimura T, Hirokawa Y, Takeda A, Ouchi A, Hareyama M, Kokubo M, Hara R, Itami J, Yamada K: Stereotactic hypofractionated highdose irradiation for stage I nonsmall cell lung carcinoma: clinical outcomes in 245 subjects in a Japanese multiinstitutional study. Cancer 2004;101:1623-1631.

-4 Timmerman P, Papiez L, McGarry R, Likes L, DesRosier C, Frost S, Williams M: Extracranial stereotactic radioablation: results of a phase I study in medically inoperable stage I non-small cell lung cancer. Chest 2003;124:1946-1955.

5 Uematsu M, Shioda A, Suda A, Fukui T, Ozeki Y, Hama Y, Wong JR, Kusano S: Computed tomography-guided frameless sterotactic radiotherapy for stage I nonsmall cell lung cancer: a 5-year experience. Int J Radiat Oncol Biol Phys 2001;51:666-670.

-6 Overgaard M: Spontaneous radiation-induced rib fractures in breast cancer patients treated with postmastectomy irradiation. A clinical radiobiological analysis of the influence of fraction size and dose-response relationships on late bone damage. Acta Oncol 1988;27:117-122.

>7 Norihisa Y, Nagata Y, Takayama K, Matsuo Y, Sakamoto T, Sakamoto M, Mizowaki T, Yano S, Hiraoka M: Stereotactic body radiotherapy for oligometastatic lung tumors. Int J Radiat Oncol Biol Phys 2008;72:398-403.

$>8$ Dajczman E, Gordon A, Kreisman H, Wolkove N: Long-term postthoracotomy pain. Chest 1991;99:270-274.

9 Reboul FL: Radiotherapy and chemotherapy in locally advanced non-small cell lung cancer: preclinical and early clinical data. Hematol Oncol Clin North Am 2004;18:41-53.

10 Green J, Kirwan J, Tierny J, Vale C, Symonds P, Fresco L, Williams C, Collingwood M: Concomitant chemotherapy and radiation therapy for cancer of the uterine cervix. Cochrane Database Syst Rev 2005;3:CD002225.

11 Haddad RI, Wirth L, Posner MR: Integration of chemotherapy in the curative treatment of locally advanced head and neck cancer. Expert Rev Anticancer Ther 2003;3:331-338.

12 Andreassen CN, Alsner J: Genetic variants and normal tissue toxicity after radiotherapy: a systematic review. Radiother Oncol 2009;92:299-309. 